\title{
Effect of Obesity to Salivary Flow Rate and Buffer Capacity
}

\author{
Yumi Lindawati \\ Department of Oral Biology \\ Faculty of Dentistry, Universitas Sumatera Utara \\ Medan, Indonesia \\ drg.yumi@yahoo.com
}

\author{
Darmayanti Siregar \\ Department of Dental Public Health \\ Faculty of Dentistry, Universitas Sumatera Utara \\ Medan, Indonesia
}

\author{
Lilia Sarifatamin Damanik \\ Undergraduate Student \\ Faculty of Dentistry, Universitas Sumatera Utara \\ Medan, Indonesia
}

\begin{abstract}
Obesity is one of the criteria of nutritional status parameters caused by the accumulation of fat that occurs gradually and influenced by many factors, one of which is the low of physical activity. Differences in nutritional status that occur in each individual leads to the differences in salivary secretion. Saliva flow rate describes the normal, high, low, or very low of the salivary flow. The changes in age, environmental conditions, life and diet affect the presence or absence of impaired salivary function. The objective of this study is to find out the differences of the flow rate and capacity of salivary buffer on the student of dentistry of USU with normal body mass index and obesity. This study is an analytical observational research with cross sectional approach. The sampling of stimulated saliva of the student of Dentistry USU was conducted in the Laboratory of Oral Biology of Dentistry USU using draining method by consecutive sampling according to the inclusion and exclusion criteria. The saliva flow rate was obtained by measuring the collected saliva in 5 minutes in the saliva pot, while for the salivary buffer capacity measurement using GC Saliva Check Buffer. Data analysis using Post-Hoc ANOVA test showed significant difference in salivary flow rate of subjects with normal body mass index and obesity (p $<0.05)$ so that there was a correlation of body mass index with salivary flow rate $(p<0,05)$ but there was no significant difference in salivary buffer capacity $(p<0.05)$. Meanwhile, the Pearson correlation test showed a significant correlation between salivary buffer capacity and salivary flow rate $(p<0.05)$. So it can be concluded that the difference of body mass index will be related to the salivary flow rate which will affect salivary buffer capacity.
\end{abstract}

Keywords-obesity, salivary flow rate, salivary buffer capacity

\section{INTRODUCTION}

Obesity is caused by the accumulation of fat that occurs gradually and is affected by the low physical activity. Soegih (2009), obesity is caused by various factors, from the results showed that obesity influenced $\pm 70 \%$ by environmental factors and $\pm 30 \%$ by genetic factors [1]. Obesity can be measured by using Body
Mass Index (BMI). Body mass index is a statistical measurement of the body weight and height of an individual used to classify individuals into categories based on body weight. Body mass index is often used as a screening tool for health problems, one of which is determining the nutritional status. Differences in nutritional status that occur in each individual can cause differences in salivary secretion [2].

Saliva is a fluid that functions in the main defense mechanisms of microorganisms in the oral cavity. Changes in age, environmental conditions, life and diet affect the function of saliva. Changes in salivary flow rate may cause changes in buffer capacity $[2,3,4]$.

Both developed and developing countries have increased prevalence of overweight and obesity. WHO regards this trend as a global emergency of health problems. Based on indicators of abdominal circumference, the prevalence of central obesity at age 18 years and over in the highest percentage of $26.6 \%$. Therefore, more nutrition in adolescents is a nutritional problem that must be addressed because it deals with health problems in young adults $[5,6,7]$.

Based on the above statements the researchers wanted to conduct the research to determine the effect of obesity on salivary flow rate and buffer capacity on Dentistry Faculty's students of USU.

\section{MATERIALS AND METHODS}

The design of this study is cross sectional study, with the method of sampling successively. The subjects were 20 persons and met the inclusion criteria (ages 1825 , good general health condition, male and female, and willing to participate in the study) and exceptions (using orthodontic devices, taking antihypertensive drugs, antidepressants, antihistamines, smokers, alcohol drinkers, women during menstruation, pregnancy, breastfeeding, history of systemic diseases, has dental caries and roots).

Sampling of stimulated saliva is done after obtaining approval from the Medical Research Ethics Committee of the Faculty of Medicine, Universitas 
Sumatera Utara and the patient has signed an informed concern sheet to be a sample. The sampling technique using the draining method, the subjects were asked to chew wax paraffin, saliva accommodated on saliva pot for 5 minutes and labeled. Saliva flow rate ( $\mathrm{ml} /$ minute) and buffer capacity was measured using GC saliva check buffer.

In the GC saliva check buffer, normal values of mean salivary flow stimulated in healthy individuals range from 1.0 to $3.0 \mathrm{ml} / \mathrm{min}$. If the value is below 0.7 $\mathrm{ml} / \mathrm{min}$ then the condition is hyposalivated and if between $0.1-0.25 \mathrm{ml} / \mathrm{min}$ then the value is very low (dry mouth syndrome). While the salivary buffer capacity, the measurement result based on the GC indicator saliva check buffer is the sum of 3 pad on the buffer strip (green $=4$ point, turquoise blue $=3$ point, blue $=2$ point, bluish red $=1$ point, red $=0$ point) $0-5$ is very low, 6-9 is low, and 10-12 is normal [8].

\section{RESULTS}

Table I shows the majority of women have normal body mass index whereas the majority of men have body mass index of obesity. In addition, for the age group the majority of subjects studied aged 21-23 years.

\begin{tabular}{|c|c|c|c|c|c|c|}
\hline \multirow{2}{*}{$\begin{array}{l}\text { Body } \\
\text { Mass } \\
\text { Index }\end{array}$} & \multicolumn{3}{|c|}{ Gender (\%) } & \multicolumn{3}{|c|}{ Age (\%) } \\
\hline & Male & Female & $\mathbf{N}$ & $18-20$ & $21-23$ & $24-26$ \\
\hline $\begin{array}{c}\text { Normal } \\
(>18.5- \\
<24.9)\end{array}$ & $\begin{array}{c}1 \\
(10)\end{array}$ & $\begin{array}{c}9 \\
(90)\end{array}$ & $\begin{array}{c}10 \\
(100)\end{array}$ & $\begin{array}{c}2 \\
(20)\end{array}$ & $\begin{array}{c}8 \\
(80)\end{array}$ & 0 \\
\hline $\begin{array}{r}\text { Obesity } \\
(>27.0)\end{array}$ & $\begin{array}{c}6 \\
(60) \\
\end{array}$ & $\begin{array}{c}4 \\
(40)\end{array}$ & $\begin{array}{c}10 \\
(100)\end{array}$ & $\begin{array}{c}5 \\
(50) \\
\end{array}$ & $\begin{array}{c}4 \\
(40) \\
\end{array}$ & $\begin{array}{c}1 \\
(10)\end{array}$ \\
\hline
\end{tabular}

Table II shows the average saliva flow rate based on body mass index in the normal category is higher than obesity is $1.18 \pm 0.61 \mathrm{ml} / \mathrm{min}$ while obesity is $0.74 \pm 0.21$ $\mathrm{ml} / \mathrm{min}$. T-Test result significance of $\mathrm{p}<0.05$ i.e. there is a significant difference of saliva flow rate between normal body mass index and obesity in FKG USU's students.

TABLE II. THE AVERAGE RATIO OF SALIVARY FLOW RATES BASED ON BODY MASS INDEX OF THE SUBJECTS $(\mathrm{N}=20)$

\begin{tabular}{|c|c|c|c|c|c|}
\hline \multirow[b]{2}{*}{$\begin{array}{l}\text { Body Mass } \\
\text { Index }\end{array}$} & \multicolumn{3}{|c|}{ Salivary Flow Rate (ml/min) } & \multirow{2}{*}{$\begin{array}{c}\text { Average } \\
\text { of salivary } \\
\text { flow rate } \\
(\mathrm{ml} / \mathrm{min})\end{array}$} & \multirow[b]{2}{*}{$\begin{array}{l}\text { Signifi- } \\
\text { cant }(p)\end{array}$} \\
\hline & $\begin{array}{l}\text { Normal } \\
\text { (n) }\end{array}$ & $\begin{array}{c}\text { Low } \\
(\mathbf{n})\end{array}$ & $\begin{array}{c}\text { Hyposalivation } \\
\text { (n) }\end{array}$ & & \\
\hline $\begin{array}{c}\text { Normal } \\
(>18.5- \\
<24.9)\end{array}$ & $\begin{array}{l}1.6 \\
(6)\end{array}$ & $\begin{array}{l}0.8 \\
(2)\end{array}$ & $\begin{array}{l}0.4 \\
(2)\end{array}$ & $1.18 \pm 0.61$ & \multirow[t]{2}{*}{${ }^{\mathrm{a}} 0.046^{*}$} \\
\hline $\begin{array}{c}\text { Obesity } \\
(>27.0)\end{array}$ & 0 & \begin{tabular}{|c}
0.92 \\
$(5)$
\end{tabular} & $\begin{array}{c}0.56 \\
(5)\end{array}$ & $0.74 \pm 0.21$ & \\
\hline
\end{tabular}

Table III represent the salivary buffer capacity in the obesity body mass index category shows the majority of subjects had low buffer capacity. While in the normal body mass index category, the number of subjects with normal and low salivary buffer capacity had a balanced amount. T-Test significant value of $\mathrm{p}>0.05$, there is no significant relationship between buffer capacity and salivary flow rate.
TABLE III. THE AVERAGE COMPARISON OF SALIVARY BUFFER CAPACITY BASED ON BODY MASS INDEX OF THE SUBJECT $(\mathrm{N}=20)$

\begin{tabular}{|c|c|c|c|c|c|}
\hline \multirow{2}{*}{$\begin{array}{c}\text { Body Mass } \\
\text { Index }\end{array}$} & \multicolumn{3}{|c|}{$\begin{array}{c}\text { Buffer Capacity } \\
\text { (n) }\end{array}$} & $\begin{array}{c}\text { Average } \\
\text { buffer } \\
\text { capacity }\end{array}$ & $\begin{array}{c}\text { Significant } \\
\text { (p) }\end{array}$ \\
\cline { 2 - 5 } & Normal & Low & Very Low & \\
\hline $\begin{array}{c}\text { Normal } \\
(>18.5- \\
<24.9)\end{array}$ & $\begin{array}{c}10.8 \\
(5)\end{array}$ & $\begin{array}{c}8.6 \\
(5)\end{array}$ & 0 & $9.7 \pm 1.3$ & ${ }^{\mathrm{c}} 0.242$ \\
\hline $\begin{array}{c}\text { Obesity } \\
(>27.0)\end{array}$ & 10 & 8.3 & 0 & $9 \pm 1.2$ & \\
\hline
\end{tabular}

Table IV shows that the results of analysis using Pearson Correlation Test which significant at $\mathrm{p}<0.05$ there is significant relationship between salivary flow rate and salivary buffer capacity without considering the body mass index of the subject.

TABLE IV. SALIVARY FLOW RATE ANALYSIS RESULTS WITH THE SALIVARY BUFFER CAPACITY OF THE SUBJECT $(\mathrm{N}=20)$

\begin{tabular}{|c|c|c|}
\hline Variable & Salivary buffer capacity & Significant (p) \\
\hline Salivary Flow Rate & $1.94 \pm 18.7$ & ${ }^{\mathrm{d}} 0.019^{*}$ \\
\hline
\end{tabular}

\section{DISCUSSION}

The results of the study on gender demographic data (Table I) showed that obesity body mass index was higher in male gender than female. Conversely, on the normal body mass index more on the subject of the female. In the research conducted by Wardani in 2015, stated that based on the body mass index, approximately $25.4 \%$ male students are obese more than female students of $12 \%$. Even though the gender is one of the factors affecting body mass index, statistical analysis shows that there is no significant difference in the distribution of obesity categories in body mass index between men and women [9]. Then, the age of 21-23 in the category of normal body mass index is the most subjects, whilst in the category of body mass index of obesity is the age of 18-20 years is the most. In early adulthood, obesity is a problem that is considered serious because it is related to the appearance of an individual that can affect his/her social life. The irregular eating pattern will cause an imbalance between the energy needed by the body and food as energy producers. This makes someone able to suffer from obesity $[10,11]$.

The respondents in this study were young adults aged 18-25 years old. In Indonesia, according to RISKESDAS data in 2013, the prevalence of obese population $>18$ years old in 2013 is $26.3 \%$, higher than in 2007 which is $13.9 \%$ and in 2010 that is $11.65 \%$ $[5,6,7]$. In research done by Kasengke et al. in 2015 the respondents with overweight were not only determined by one factor alone but various factors including diet, exercise, lifestyle, environment, genetic and socioeconomic. Therefore it is very important to maintain the weight in order to avoid obesity, especially in young adulthood. Setting a diet with a good diet, regular exercise, and a good lifestyle is a fairly effective way to maintain and prevent the occurrence of abnormal body mass index in young adulthood [10,11]. 
The results of the study on the average salivary flow rate (Table II) showed a significant difference in salivary flow rate between normal body mass index and obesity. In the normal body mass index category, the average salivary flow rate is $1.2 \mathrm{ml} / \mathrm{min}$ and obesity category is $0.74 \mathrm{ml} / \mathrm{min}$. This result is lower than that found by Modeer et al. in 2010 where the average stimulated salivary flow rate in the normal body mass index is $2.0 \mathrm{ml} / \mathrm{min}$ and the obesity category is 1.2 $\mathrm{ml} / \mathrm{min}$. This was due to the differences in the way of taking the flow rate of stimulated saliva, where this study was using the method of draining, whilst the previous study was using spitting method [12]. Wong in 2008 stated that the results of sampling salivary flow rate by using spitting method is higher than using draining method, in which the statement is in line with the results of this study [13].

The normal body mass index category tends to have a normal salivary flow rate while obesity has a tendency to be lower even hyposalivation. This is in line with research conducted by Fajrin et al. in 2015 who stated that the salivary flow rate in the subjects with normal body mass index would have normal salivary flow rates while subjects with the obesity body mass index would have lower salivary flow rates than the underweight and even the overweight would have hyposalivation [4].

Pannuzio in 2010 stated that overweight and obese individuals have the potential to experience xerostomia and increasing caries risk than individuals with a normal BMI [9]. Obesity causes numbers of cytokines which increase in the inflammatory response in some organs of the body resulting in chronic inflammation. With the inflammation, the function of the hypothalamic-pituitary-adrenal axis affecting the neuroendocrine regulation of the salivary glands will be changed, resulting in the reduced of salivary secretion [11].

The results of this study were supported by Inoue et al. in 2006 who stated that BMI is positively correlated with the size of salivary gland, where the size of the parotid and submandibular glands in underweight individuals is smaller than individuals with a normal BMI [14].

In addition, Modeer et al in 2010 mentioned that salivary flow rate will be reduced in the individual who has a BMI value greater than 25 on adult samples because obese individuals have an increased number of adipocytes in the salivary gland parenchyma tissue. Proinflammatory cytokines derived from adipocytes and macrophages accumulate in adipose tissue and affect salivary gland function $[2,12]$.

On the other hand, although the body mass index describes the overall body composition (fat, muscle, bone), Lestari in 2015 suggest that there is no relationship between body mass index and percent body fat. This is evidenced by her research that is although individuals who eat foods with high-fat content seems related to obesity but statistically did not show the relationship of percent body fat with body mass index [1].
The results on salivary buffer capacity (Table III) in this study showed that the average salivary buffer capacity in normal body mass index category was higher than obesity but not significant. Saliva buffer capacity is affected by diet. Indriana in 2011 stated that the consistency and volume of food have an effect on to salivary flow rate and buffer capacity $[9,12,15]$. Pradanta et al. in 2016 revealed that diets high in carbohydrate may decrease salivary buffer capacity, whereas a diet high in fiber and a diet high in protein have the effect of increasing salivary buffer [16]. This is supported by Andriani in 2012 who stated that obese individuals will experience a metabolic disruption caused by the number of carbohydrates consumed. Hence researchers estimated that subjects with body mass index in obesity category consume lots of carbohydrates that cause a decrease in buffer capacity, but this requires further research that traces the number of carbohydrates consumed. However, Merinda in 2013 stated that there is no significant relationship between $\mathrm{pH}$ value and buffer capacity depends on diet $[17,18]$.

The result analysis of salivary flow rate and buffer capacity (Table IV) showed a significant relationship. This is in line with Merinda et al. in 2013 who mentioned that salivary buffer capacity is related to salivary flow rate. The high salivary flow rate will cause the buffer capacity to be high [20]. The salivary glands can be stimulated by mechanical stimulation which is with mastication. In this study, subjects were asked to chew wax paraffin so that it can stimulate salivary secretion. The process of chewing is a mechanical stimulus that stimulates the increasing of salivary secretion whereas tasting is sensory information which related to chemical stimuli that can increase salivary flow rate and buffer capacity $[16,18]$.

As a conclusion in this research, there was a significant difference of salivary flow rate between normal body mass index and obesity on students of Dentistry USU $(\mathrm{p}<0.05)$. But there was no significant difference in salivary buffer capacity between normal body mass index and obesity on students of Dentistry USU ( $\mathrm{p}>0.05)$.

There was a significant relationship between salivary flow rate and buffer capacity $(\mathrm{p}<0.05)$. It was evidenced by the changes in salivary flow rate causes a change in salivary buffer capacity.

As a recommendations in this research, it is important to maintain the body mass index in normal value, obesity caused effect to body health include oral health. We know that saliva's function is to maintain oral health, so the salivary should be in normal condition. For obesity sufferers, should drink more water or chewing gum, eat or drink sour taste to stimulate more saliva out.

\section{ACKNOWLEDGMENT}

This research is funded by Lembaga Penelitian Universitas Sumatera Utara with contract number 5338/UN5.1.R/PPM/2017. 


\section{REFERENCES}

[1] J.W. Lestari, "The relationship between percent body fat, body mass index and haemoglobin level with written test on students of SMA Ipiems Surabaya," J. Antro. Unairdot. Net., vol. 4(1), pp. 22-26, 2015.

[2] WHO. (2016, September) Body mass index-BMI. Available: http:// www.euro.who.int/en/health-topics/diseaseprevention/nutrition/a-healthy lifestyle/body-mass-index-bmi.

[3] A.K. Pandey, "Physiology of saliva: an overview," J. Dent. Ind., vol. 21(1), pp. 32-38, 2014

[4] F.N. Fajrin, Z. Agus, N. Kasuma, "The relationship between body mass index and salivary flow rate (study on the students in Faculty of Dentistry University Andalas)," Maj. Ked. Gi. Ind., vol. 1(2), pp. 156-162, December 2015.

[5] I. Mulyasari, S.F. Muis, A. Kartini, "The effect of water intake on body weight, body mass index, and percent body fat in adolescent girls who experience over nutrition," J. Gizi Ind., 3(2), pp. 120-5, June 2015.

[6] Agency for Research and Health Development RI, Report on the results of riset kesehatan dasar (RISKESDAS) of North Sumatera 2007, Medan, 2009, pp. 36-41.

[7] Ministry of Health RI, Basic health research, Jakarta, 2013, 22330.

[8] D. Animireddy, R.T.V. Bekkem, P. Vallala, et al., "Evaluation of $\mathrm{pH}$, buffering capacity, viscosity and flow rate leves of saliva in caries-free, minimal caries and nursing caries children: An in vivo study," Comtemp. Clin. Dent., vol. 5(3), pp. 324-326, 2014.

[9] D.A.K. Wardani, E. Huriyati, Mustikaningtyas, J. Hastuti, "Obesity, body image, and feelings of stress on students in
Yogyakarta Special Region,” J. Gizi Klinik Indo., vol. 11(4), pp. 161-169, 2015

[10] The relationship of obesity and the body image of the students of the faculty of cultural science of University of Indonesia (FIB UI). Depok: University of Indonesia. 2012, 5.

[11] J. Kasengke, Y.A. Assa, M.E. Paruntu, "Prediction of shortly sugar content in young adults aged 20-30 years with body mas index (IMT) $\geq 23 \mathrm{~kg} / \mathrm{m}^{2}$," J. eBm., vol. 3(3), pp. 851-855, 2015.

[12] Modéer, Thomas, C.B. Cecilia, W. Biniyam, J. Annika, M Claude, "Association between obesity, flow rate of whole saliva, and dental caries in adolescents," vol. 18, pp. 2367-2373, 2010.

[13] D.T. Wong, Salivary diagnostics, USA: Wiley-Blackwell; 2008 $39-42$.

[14] H. Inoue, K. Ono, W. Masuda, et al., "Gender difference in unstimulated whole saliva flow rate and salivary gland sizes," Arch. Oral Biol., vol. 51, pp. 1055-1060, 2006.

[15] T. Indriana, "Differences between salivary flow rate and $\mathrm{pH}$ due to the influence of chemical and mechanical stimuli," J. Kedokt. Meditek., vol. 17(44), pp. 1-5, Mei 2011.

[16] Y.E. Pradanta, R. Adhani, I.H. Khatimah, "The correlation of $\mathrm{pH}$ level and salivary volume to the caries index of Menginang people in Lokpaikat, Tapin (Observational study with saliva sampling of spitting method)," J. Dent. Ked. Gigi, vol. 1(2), pp. 158-163, 2016

[17] P. Winarni, H. Hirawati, L. Dian, The relationship between knowledge about balanced nutrition with the behaviour of balanced nutrition fulfilment on students grade XI SMA Negeri 1 Ungaran, Semarang: STIKES Ngudi Waluyo, 2014, pp. 6

[18] W. Merinda, D.E. Indahyani, Y.C. Rahayu, 'The relationship of $\mathrm{pH}$ and salivary buffer capacity to caries index of SLB-A students Bintoro Jember,” JIHPM, pp. 1-5, 2013. 